\title{
Effect of co-morbidities on disease course in human immunodeficiency virus-infected illicit drug users in the era of highly active antiretroviral therapy
}

\author{
Venkataramana Kandi \\ Department of Microbiology, Prathima Institute of Medical Sciences, Karimanagr, India
}

Human immunodeficiency virus (HIV), the causative agent of acquired immunodeficiency syndrome (AIDS), has been responsible for severe morbidity and mortality worldwide. Since its discovery in 1980, HIV infection has assumed prominent significance among other prevalent infectious diseases worldwide. It has been very difficult for physicians and health care workers to promote public understanding of HIV infection because of social proscriptions of some behaviors associated with HIV; however, there have been significant developments in the scientific understanding of the causative virus, modes of transmission, laboratory diagnosis and treatment of HIV infection in the last decade. HIV infection alone has been noted to influence haematological [1] and biochemical parameters [2], leading to anaemia, lymphocytopaenia [3], and liver and cardiovascular abnormalities $[4,5]$. The initiation of highly active antiretroviral therapy (HAART) in individuals with these symptoms may contribute to further worsening of the disease and result in further morbidity and mortality [6,7]. The disease course of $\mathrm{HIV}$ is influenced by the presence of co-morbidities that include infectious diseases like tuberculosis (TB), hepatitis B virus (HBV), and hepatitis $\mathrm{C}$ virus (HCV) as well as malignancies. Other factors that influence disease management and antiretroviral therapy in the HIV-infected population are illicit drug use and malnourishment. Therefore, identification of various co-

Correspondence: Venkataramana Kandi

Department of Microbiology, Prathima Institute of Medical Sciences,

Nagunur, Karimnagar 505 417, India

Tel: +91-8728222779, Fax: +91-8728222779

Email: ramana_20021@rediffmail.com

Received: Jan 11, 2015, Accepted: Feb 18, 2015, Published: Feb 18, 2015

This article is available from: http://e-epih.org/

(C) 2015, Korean Society of Epidemiology

(C) This is an open-access article distributed under the terms of the Creative Commons Attribution License (http://creativecommons.org/licenses/by/3.0/), which permits unrestricted use, distribution, and reproduction in any medium, provided the original work is properly cited. morbidities prior to the initiation of HAART is necessary to minimise related additional complications and resultant morbidity and mortality.

Illicit drug users are among the individuals most predisposed to contract HIV and other blood-borne infectious agents. There is not much data available globally on the influence of co-morbidities and treatment challenges faced when treating HIV-positive individuals with comorbid substance use disorders.

Addiction is defined as a psychological condition in which an individual has a craving for a substance and uses the substance compulsively and repeatedly in spite of knowing its harmful effects [8]. Alcohol and nicotine are among the most commonly abused substances worldwide due to their availability and affordability. Other substances of abuse are cocaine, heroin, opium, ketamine, methamphetamine and many others. The HIVpositive population has been noted to have a higher chance of developing drug abuse and infectious diseases than HIV-negative individuals, which could be attributed to behavioural (sharing injecting equipment), sociocultural (marginalisation and stigmatisation of HIV-positive people), environmental (reduced accessibility to healthy living conditions, limited access to sterile syringes), and infrastructural factors (minimal access to addiction treatment programmes) that increase the chance of disease transmission [9]. Moreover, illicit drug users with comorbid HIV infection have a greater chance of developing complications from antiretroviral therapy than drug users without HIV infection. HIV-positive illicit drug users, compared with HIVpositive individuals, have significantly higher chances of developing other infections like tuberculosis [10], HBV and HCV $[11,12]$, herpes simplex virus and many others including sexually transmitted diseases [13] like syphilis [14] and gonorrhoea.

Recent studies have reported that increased disease burden [15], mental illness [16], cause-specific disability-adjusted life years and years lost because of disability are significantly related to illicit drug use [17]. Studies have also observed that sub- 
stances of abuse may enhance viral replication and reduceTCD4 ${ }^{+}$ cell count and thereby hasten the progression of HIV-related disease [18]. Illicit drug use has been noted to predispose individuals to infection with HIV (9 to $12 \%), \mathrm{HCV}(50 \%)$ and hepatitis A virus (2\%) in the US [19]. Comorbidities in HIV-infected illicit drug users may vary in different geographical regions, as evidenced by an Indian study that noted a greater prevalence of oral candidiasis (43.2\%), TB (33.9\%) and anaemia $(22 \%)$ among this population [20]. Considering that the majority of patients diagnosed as HIV-seropositive are in their most productive years of life, a better knowledge of the prevalence of co-morbidities and substance abuse in such individuals assumes significance for better patient care $[21,22]$.

Therefore, identification of patients with HIV infection and associated co-morbidities, including substance abuse, becomes very important for improved clinical management. Strengthening of primary care for the HIV-infected population should be considered a first step towards better HIV disease management. The voluntary counselling and testing program which is available in most parts of the world where HIV is prevalent for those using illicit drugs should be revitalised to promote early diagnosis and better understanding of substance abuse disorders. Identification of the factors contributing to substance abuse in HIVpositive patients and planning strategies for treatment of addiction, as well as motivating patients to undertake antiretroviral therapy with regular follow-up would contribute to improved quality of life in such individuals.

Public health strategies such as vaccination, pre-vaccination testing programmes, outreach initiatives to engage high risk populations, regular monitoring for treatment adherence, and peer counselling about the adverse effects of substance abuse on the HIV disease course and antiretroviral therapy would also contribute to improved management of HIV seropositive patients. Finally, education about the importance of safe sex practices and sterile injection practices, facilitating self-assessment of risk for contracting infectious diseases, and promoting participation in treatment programmes for substance abuse will synergistically be instrumental in the management of HIV-seropositive patients using illicit drugs and in reducing morbidity and mortality and increasing quality of life in the era of HAART. In conclusion, there is a pressing need for epidemiologial studies on the prevalence of co-morbidities among HIV-infected illicit drug users and the formulation of strategies to provide effective health care in these patients.

\section{CONFLICT OF INTEREST}

The author has no conflicts of interest to declare for this study.

\section{REFERENCES}

1. Ramana KV, Chary J, Sabitha V, Mohanty SK, Rao R. Role of hematological and alternate markers in human immunodeficiency virus disease progression. Am Med J 2010;1:84-87.

2. Ramana KV, Rao R, Sabitha, Venugopal B, Rafi MD, Sanjeeva RD. Biochemical parameters in human immunodeficiency virus disease progression. J Med Microbiol Diagn 2012;1:103.

3. Kandi V. A study of biological markers in HIV disease progression and management in the highly active antiretroviral therapy (HAART) era. Am J Biosci Bioeng 2013;1:24-37.

4. Ramana KV. HIV disease management in the highly active antiretroviral therapy (HAART) era. J Med Microbiol Diagn 2012;1:e101.

5. Ramana KV, Rao R, Sabitha. Abnormal levels of $\gamma$-glutamyl transpeptidase (GGTP), ALT, AST in human immunodeficiency virus-1 (HIV-1) infection. Biochem Physiol 2012;1:101.

6. Ramana KV, Rao R. Human immunodeficiency virus disease management in highly active antiretroviral therapy era: a comprehensive review. Ann Trop Med Public Health 2013;6:5-9.

7. Ramana KV, Rao R. Noninfectious complications in HIV disease: need for rational changes in HIV disease management in the highly active antiretroviral therapy era. Ann Trop Med Public Health 2013; 6:383-385.

8. Nestler EJ. Cellular basis of memory for addiction. Dialogues Clin Neurosci 2013;15:431-443.

9. Latkin CA, Knowlton AR. Micro-social structural approaches to HIV prevention: a social ecological perspective. AIDS Care 2005; 17 Suppl 1:S102-S113.

10. Pevzner ES, Robison S, Donovan J, Allis D, Spitters C, Friedman R, et al. Tuberculosis transmission and use of methamphetamines in Snohomish County, WA, 1991-2006. Am J Public Health 2010;100:24812486.

11. Bao YP, Liu ZM. Systematic review of HIV and HCV infection among drug users in China. Int J STD AIDS 2009;20:399-405.

12. Chu FY, Chiang SC, Su FH, Chang YY, Cheng SH. Prevalence of human immunodeficiency virus and its association with hepatitis $\mathrm{B}$, $\mathrm{C}$, and $\mathrm{D}$ virus infections among incarcerated male substance abusers in Taiwan. J Med Virol 2009;81:973-978.

13. Semaan S, Des Jarlais DC, Malow RM. Sexually transmitted diseases among illicit drug users in the United States: the need for interventions. In: Aral SO, Jr Douglas JM, Lipshutz JA, editors. Behavioral interventions for prevention and control of sexually transmitted diseases. New York: Springer; 2007, p. 397-430.

14. Wang LJ, Lin SK, Chiang SC, Su LW, Chen CK. Risk factors for HIV, viral hepatitis, and syphilis among heroin users in northern Taiwan. Subst Use Misuse 2013;48:89-98.

15. Degenhardt L, Whiteford HA, Ferrari AJ, Baxter AJ, Charlson FJ, Hall WD, et al. Global burden of disease attributable to illicit drug use and dependence: findings from the Global Burden of Disease Study 2010. Lancet 2013;382:1564-1574.

16. Whiteford HA, Degenhardt L, Rehm J, Baxter AJ, Ferrari AJ, Erskine HE, et al. Global burden of disease attributable to mental and substance use disorders: findings from the Global Burden of Disease Study 2010. Lancet 2013;382:1575-1586.

17. Gore FM, Bloem PJ, Patton GC, Ferguson J, Joseph V, Coffey C, et al. Global burden of disease in young people aged 10-24 years: a systematic analysis. Lancet 2011;377:2093-2102.

18. Li Y, Zhang T, Douglas SD, Lai JP, Xiao WD, Pleasure DE, et al. Morphine enhances hepatitis $\mathrm{C}$ virus (HCV) replicon expression. Am J Pathol 2003;163:1167-1175. 
19. Prejean J, Song R, Hernandez A, Ziebell R, Green T, Walker F, et al. Estimated HIV incidence in the United States, 2006-2009. PLoS One 2011;6:e17502.

20. Solomon SS, Hawcroft CS, Narasimhan P, Subbaraman R, Srikrishnan AK, Cecelia AJ, et al. Comorbidities among HIV-infected injection drug users in Chennai, India. Indian J Med Res 2008;127:447452.

21. Donoghoe MC, Verster A, Pervilhac C, Williams P. Setting targets for universal access to HIV prevention, treatment and care for injecting drug users (IDUs): towards consensus and improved guidance. Int J Drug Policy 2008;19 Suppl 1:S5-S14.

22. Des Jarlais DC, Semaan S, Arasteh K. At 30 years: HIV/AIDS and other STDs among persons who use psychoactive drugs. In: Hall JC, Hall BJ, Cockerell CJ, McKeon M, editors. HIV/AIDS in the postHAART era: manifestations, treatment, and epidemiology. Shelton: People's Medical Publishing House; 2011, p.753-778. 